Ljiljana Avramović ${ }^{*}$, Zoran Stevanović ${ }^{1}$, Mile Bugarin ${ }^{1}$, Radojka Jonović ${ }^{1}$ Radmila Marković ${ }^{1}$, Vojka Gardić ${ }^{1}$, Marko Jonovic ${ }^{2}$, Jelena Đorđević ${ }^{1}$

${ }^{1}$ Mining and Metallurgy Institute Bor, Bor, Serbia,

${ }^{2}$ University of Belgrade, Institute of Chemistry, Technology and Metallurgy, Belgrade, Serbia

Scientific paper

ISSN 0351-9465, E-ISSN 2466-2585

UDC:631.421/.425(497.11)

doi:10.5937/ZasMat1603378A

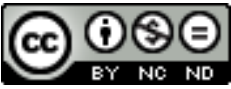

Zastita Materijala 57 (3)

378 - 382 (2016)

\title{
Characterization of soil in the coastal area of the Bor River
}

\begin{abstract}
Production process of copper obtaining in the Mining and Smelting Company (RTB) Bor directly affects the environmental pollution in Bor and surrounding area. Harmful elements present in the air are deposited on the surface and due to the effects of atmospheric precipitation penetrate into deeper layers of soil. On the other hand, in the area of RTB Bor activity, the significant pollution of rivers and soil are present in coastal area due to the increased concentrations of present heavy metals. The Bor River is particularly endangered where the waste industrial and mining waste water flew for many years. The Bor River has become on time one of the most polluted rivers in Europe.

This paper presents the results of physico-chemical characterization of soil samples from the coastal areas of the Bor River. The following parameters were analyzed: moisture content, $\mathrm{pH}$ value, bulk density, specific gravity, grain size distribution, chemical composition, toxic characteristics -TCLP Method and leaching test - Method for characterization of waste leaching.

The obtained results indicate that the soil is contaminated with heavy metals and that a significant deviation from the permissible concentrations was found in particular for the following elements: $\mathrm{Cu}$, As, and Pb. The soil in the coastal area of the Bor River belongs to the category of hazardous waste and the preventive measures are necessary in accordance with defined regulations.
\end{abstract}

Keywords: soil, characterization, Bor River.

\section{INTRODUCTION}

Soil pollution with heavy metals is not easy to define and varies in different types of soil. The presence of a compound in a certain amount does not have to cause a disruption in the plant production in one type of soil, but its presence in the other type of soil, can reduce the quality and quantity of yield.

Today, these elements are far more present in the agricultural land, although they were no present in such content in the parent substrate on which the land was formed. The reason for this is the increasing number of industrial plants. There are more and more metal smelters and power plants from which large amounts of certain metals come out from stacks in the form of gases, soot and smoke.

\footnotetext{
${ }^{*}$ Corresponding author: Ljijana Avramović

E-mail:institut@irmbor.co.rs

Paper received: 15.01.2016.

Paper accepted: 17.02.2016.

Paper is available on the website:

www.idk.org.rs/journal
}

All of them mostly drop by rainfall into the soil, polluting the environment and destroying the vegetation.

In addition to the maturities of heavy metals in the soil of parent substrate from which it is also formed during pedogenesis, and other sources of their introduction must be kept in mind. The industrial plants pollute the air with heavy metals, and therefore the pollution is transferred to the land and water. In the vicinity of the smelter plants for metal processing and power plants, damages of plants and soil are often noticed

A substantial portion of heavy metals reaches to the soil by the use of chemicals in the industrial and agricultural processes. These include lead $(\mathrm{Pb})$, mercury $(\mathrm{Hg})$, nickel $(\mathrm{Ni})$ and arsenic $(\mathrm{As})$. Sources of heavy metals in the soil may also be some fertilizers and pesticides. Many heavy metals are entered by the plant protection products, and the urban garbage (municipal waste) is increasingly mentioned as a potential source of these elements.

Harmful elements present in the air as a consequence of the production process in RTB directly affect the soil pollution by depositing on the surface and due to the effects of penetration the atmospheric precipitation into deeper layers of the soil. 
Polluted acid water from the rivers [1,2] from the area of RTB activity also has a major impact on soil contamination which is particularly reflected in the coastal area. Due to these reasons, an analysis of the soils was carried out on the content of heavy metals from the coastal areas of the Bor River [3-6]

\section{METHODS}

The following methods were used for chemical characterization of soil:

- The ICP method was used for determination the content of $\mathrm{As}, \mathrm{Mn}, \mathrm{Ni}, \mathrm{Cd}, \mathrm{Ba}, \mathrm{Cu}, \mathrm{Mo}, \mathrm{Sb}$, $\mathrm{Se}$, and $\mathrm{Cr}$ on the apparatus Simultaneous ICP Optical Emission Spectrometer with Inductively Coupled Plasma.

- The AAS method on the Atomic Absorption Spectrophotometer, Perkin Elmer 2380, was used for analyzing the content of $\mathrm{Fe}, \mathrm{Zn}$ and $\mathrm{Pb}$.

- The TDM method was used for analyzing of chloride and sulfate on the apparatus TURBIDIMETER MICRO 100 LAB-IR.

- Ammonium ion and nitrate were analyzed by the SPF method on the apparatusd CECIL UV: VISIBLE SPECTROPHOTOMETER SERIES 2000.

- Mercury was determined by the A-Hg method on the mercury analyzer PERKIN ELMER, FIMS 100.

Testing the harmful effects of soil on the environment is divided in two phases and these are:

- The first phase of testing was the testing of toxic characteristics of the soil samples according to the standard method - Method 1311 Toxicity Characteristic Leaching Procedure (TCLP), "Test Methods for Evaluating Solid Waste, Physical/Chemical Methods", US EPA Publication SW-846).

- The second phase of tests of soil samples presents the leaching test that was carried out according to the accredited standard method SRPS EN 12457-2:2008 Characterization of waste-Leaching - Compliance test for leaching of granular waste materials and sludges - Part 2: One stage batch test at a liquid to solid ratio of $10 \mathrm{l} / \mathrm{kg}$ for materials with particle size below $4 \mathrm{~mm}$ (without or with size reduction).

\section{RESULTS AND DISCUSSION}

This paper presents the results of physicochemical characterization of soil samples from the coastal areas of the Bor River. The following parameters of the soil were analyzed: moisture content, $\mathrm{pH}$, bulk density, specific weight, grain size distribution, chemical composition, toxic characteristics -TCLP Method and leaching test Method for Characterization of waste leaching.

\subsection{Physical characteristics of soil samples from the valley of the Bor River}

The study also included the testing of soil from the site in the valley of the Bor River. In order to laboratory testing, the soil was sampled from the coastal area (Photo) from five sites (samples U1, U2, U3, U4 and U5) upstream from the village of Slatina on the left bank of the Bor River, which in the previous period to the nineties (and in the operational period was the Old Flotation Tailing Dump in Bor) was subjected to the flooding and pollution with flotation tailings from the Flotation Plant in Bor as well as the Old Flotation Tailing Dump in Bor. The following physical characteristics were determined (Table):

- moisture content in the samples

- natural pH value of solid samples,

- bulk density of samples,

- specific weight (density) of solid samples.

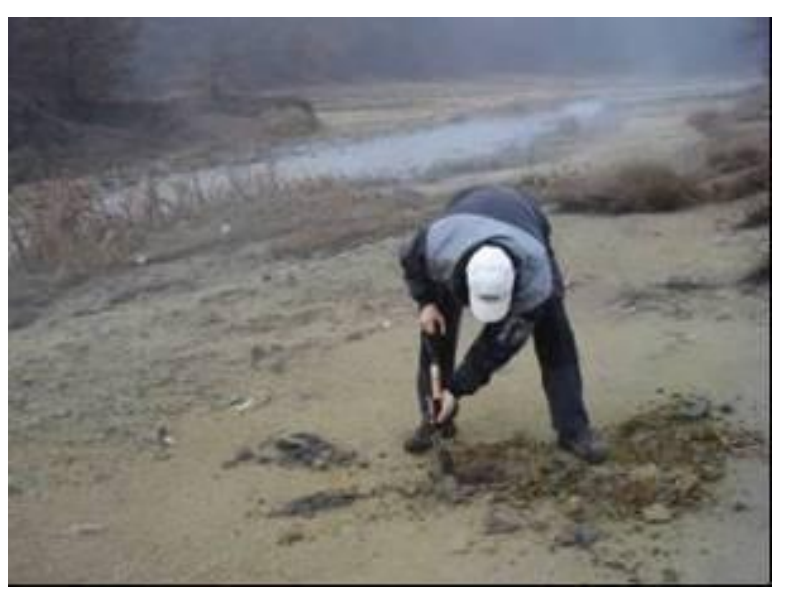

Figure 1 - Sampling of soil

Table 1 - Medium content of moisture, bulk density, density and natural $\mathrm{pH}$ value of polluted coastal land from the valley of the Bor River

\begin{tabular}{|c|c|c|c|c|}
\hline $\begin{array}{c}\text { Sample } \\
\text { designation }\end{array}$ & Moisture content, \% & $\begin{array}{c}\text { Natural pH } \\
\text { value }\end{array}$ & $\begin{array}{c}\text { Bulk density, } \\
\text { g/dm }\end{array}$ & $\begin{array}{l}\text { Medium density, } \\
\mathrm{g} / \mathrm{dm}^{3}\end{array}$ \\
\hline U1 & 16.50 & 3.09 & 1123.50 & 2.83 \\
\hline $\mathrm{U} 2$ & 25.30 & 3.23 & 1120.90 & 2.84 \\
\hline U3 & 18.04 & 3.78 & 1102.70 & 2.78 \\
\hline U4 & 12.65 & 4.57 & 1115.40 & 2.70 \\
\hline U5 & 16.90 & 4.14 & 1102.70 & 2.75 \\
\hline
\end{tabular}




\subsection{Chemical characteristics of soil samples from the valley of the Bor River}

By comparison the results obtained with maximum permitted amounts of hazardous and harmful substances, according to the Regulations on permitted amounts of hazardous and harmful substances in soil and water for irrigation and Table 2 - Chemical composition of samples from the valley of the Bor River

\begin{tabular}{|c|c|c|c|c|c|c|c|c|c|c|c|}
\hline \multirow{2}{*}{ Sample } & As & Se & Mo & Cr & Cu & Pb & Zn & Cd & Ni & Fe \\
\cline { 2 - 12 } & \multicolumn{10}{|c|}{$\%$} \\
\hline U1 & 0.011 & $<0.004$ & $<0.001$ & 0.0036 & 0.071 & 0.03 & 0.02 & $<0.001$ & $<0.01$ & 10.22 \\
\hline U2 & 0.018 & $<0.004$ & $<0.001$ & 0.0030 & 0.13 & 0.09 & 0.02 & $<0.001$ & $<0.01$ & 9.14 \\
\hline U3 & 0.0056 & 0.005 & $<0.001$ & $<0.005$ & 0.024 & $<0.01$ & 0.005 & $<0.0002$ & $<0.01$ & 3.00 \\
\hline U4 & 0.0086 & $<0.004$ & $<0.001$ & $<0.005$ & 0.029 & $<0.01$ & 0.004 & $<0.0002$ & $<0.01$ & 1.11 \\
\hline U5 & 0.017 & $<0.004$ & $<0.001$ & $<0.005$ & 0.025 & $<0.01$ & 0.007 & $<0.0002$ & $<0.01$ & 5.77 \\
\hline
\end{tabular}

\subsection{Determination the toxic characteristics of the} soil samples from the valley of the Bor River

Soil samples from the valley of the Bor River were tested in order to determine the toxic characteristics using the standard method EPA 1311, whose description is given in the previous

Table 3 - Results of chemical analysis of eluate obtained using the standard method for testing the toxic characteristics of waste (EPA 1311)

\begin{tabular}{|c|c|c|c|c|c|c|}
\hline $\begin{array}{c}\text { Sample } \\
\text { designation }\end{array}$ & U1-TCLP & U2-TCLP & U3-TCLP & U4-TCLP & U5-TCLP & Allowed concentrations $^{*}$ \\
\hline Element(mg/L) & & & & & & \\
\hline $\mathrm{As}$ & $<0.10$ & $<0.10$ & $<0.10$ & $<0.10$ & $<0.10$ & 5 \\
\hline $\mathrm{Ba}$ & 0.018 & 0.084 & 0.49 & 0.26 & 0.051 & 100 \\
\hline $\mathrm{Cu}$ & 0.52 & 1.20 & 0.31 & 0.56 & 0.057 & 25 \\
\hline $\mathrm{Sb}$ & $<0.10$ & $<0.10$ & $<0.10$ & $<0.10$ & $<0.10$ & 15 \\
\hline $\mathrm{Hg}$ & $<0.10$ & $<0.10$ & $<0.10$ & $<0.10$ & $<0.10$ & 0.2 \\
\hline $\mathrm{Cd}$ & $<0.020$ & $<0.020$ & $<0.020$ & $<0.020$ & $<0.020$ & 1.0 \\
\hline $\mathrm{Mo}$ & $<0.020$ & $<0.020$ & $<0.020$ & $<0.020$ & $<0.020$ & 350 \\
\hline $\mathrm{Ni}$ & $<0.020$ & $<0.020$ & $<0.020$ & $<0.020$ & $<0.020$ & 20 \\
\hline $\mathrm{Pb}$ & $<0.10$ & $<0.10$ & $<0.10$ & $<0.10$ & $<0.10$ & 5 \\
\hline $\mathrm{Cr}$ & $<0.020$ & $<0.020$ & $<0.020$ & $<0.020$ & $<0.020$ & 1 \\
\hline $\mathrm{Se}$ & $<0.20$ & $<0.20$ & $<0.20$ & $<0.2$ & $<0.20$ & 250 \\
\hline $\mathrm{Zn}$ & 0.35 & 0.17 & 0.26 & 0.072 & 0.19 & - \\
\hline $\mathrm{SO}_{4}{ }^{2-}$ & 222.0 & 40.7 & 5.19 & 8.71 & 16.83 & - \\
\hline $\mathrm{Cl}$ & 0.91 & 1.03 & 0.21 & 3.03 & 0.14 & - \\
\hline $\mathrm{F}^{-}$ & & & 0.16 & 0.13 & 0.13 & \\
\hline
\end{tabular}

*According to the Regulations on categories, testing and classification of waste ("Official Gazette RS", No. 56/10).

Based on the obtained results, it is concluded that the tested samples show no toxic characteristics.

\subsection{Determination the leachibility of the soil samples from the valley of the Bor River}

In further tesrting, the soil samples sampled in the valley of the Bor River were analyzed in methods of their testing ("Official Gazette RS", No. 23/94), it is concluded that the soil samples from the valley of the Bor River have an increased content of $\mathrm{As}, \mathrm{Cu}$ and $\mathrm{Pb}$ in the samples $\mathrm{U} 1$ and $\mathrm{U} 2$, the increased content of $\mathrm{As}, \mathrm{Cu}$ and $\mathrm{Pb}$ in the samples U3, U4 and U5.

chapter. The obtained results are shown in Table 3 and they are compared with the values regulated within the Regulations on categories, testing and classification of waste ("Official Gazette RS", No. $56 / 10)$. 
Table 4 - Results of chemical analysis of eluate obtained using the standard method for testing the leachibility of waste

\begin{tabular}{|l|c|c|c|c|c|c|}
\hline \multicolumn{1}{|c|}{ Sample designation } & $\begin{array}{c}\text { U1-10 } \\
\text { L/kg }\end{array}$ & $\begin{array}{c}\text { U2-10 } \\
\text { L/kg }\end{array}$ & $\begin{array}{c}\text { U3-10 } \\
\text { L/kg }\end{array}$ & $\begin{array}{c}\text { U4-10 } \\
\text { L/kg }\end{array}$ & $\begin{array}{c}\text { U5-10 } \\
\text { L/kg }\end{array}$ & $\begin{array}{c}\text { Allowed } \\
\text { concentrations }\end{array}$ \\
\hline \multicolumn{7}{|c|}{ Parameter } \\
\hline pH of eluate & 3.50 & 3.55 & 4.03 & 5.04 & 7.32 & - \\
\hline Temperature of eluate $\left({ }^{\circ} \mathrm{C}\right)$ & 21.6 & 21.9 & 20.0 & 20.0 & 20.2 & - \\
\hline $\begin{array}{l}\text { Conductivity of eluate } \\
(\mu \mathrm{S} / \mathrm{cm})\end{array}$ & 668 & 663 & 96 & 1048 & 35 & - \\
\hline \multicolumn{7}{|c|}{ Element $\left(\mathbf{m g} / \mathbf{k g}^{* *}\right)$} \\
\hline $\mathrm{As}$ & $<0.939$ & $<0.956$ & $<0.95$ & $<0.961$ & $<0.95$ & 25 \\
\hline $\mathrm{Ba}$ & 0.657 & 0.229 & 1.14 & 1.153 & 0.162 & 300 \\
\hline $\mathrm{Cu}$ & 29.1056 & 39.178 & 0.4845 & $<0.481$ & 11.46 & 100 \\
\hline $\mathrm{Sb}$ & $<0.939$ & $<0.956$ & $<0.95$ & $<0.961$ & $<0.95$ & 5 \\
\hline $\mathrm{Hg}$ & $<0.939$ & $<0.956$ & $<0.95$ & $<0.961$ & $<0.95$ & 2 \\
\hline $\mathrm{Cd}$ & $<0.1878$ & $<0.191$ & $<0.19$ & $<0.192$ & $<0.19$ & 5 \\
\hline $\mathrm{Mo}$ & $<0.1878$ & $<0.191$ & $<0.19$ & $<0.192$ & $<0.19$ & 30 \\
\hline $\mathrm{Ni}$ & $<0.1878$ & $<0.191$ & $<0.19$ & $<0.192$ & 0.717 & 40 \\
\hline $\mathrm{Pb}$ & $<0.939$ & $<0.956$ & $<0.95$ & $<0.961$ & $<0.95$ & 50 \\
\hline $\mathrm{Cr}$ & $<0.1878$ & $<0.191$ & $<0.19$ & $<0.192$ & $<0.19$ & 70 \\
\hline $\mathrm{Se}$ & $<1.878$ & $<1.911$ & $<1.9$ & $<1.922$ & $<1.9$ & 7 \\
\hline $\mathrm{Zn}$ & 7.323 & 1.529 & 1.615 & 0.240 & 21.022 & 200 \\
\hline $\mathrm{SO}{ }_{4}^{2-}$ & 3573.411 & 284.756 & 27.835 & 28.161 & 92.224 & 50000 \\
\hline $\mathrm{Cl}$ & 15.304 & 13.664 & 1.14 & 0.673 & 12.04 & 25000 \\
\hline $\mathrm{F}$ & & & 1.235 & 1.057 & 1.15 & 500 \\
\hline
\end{tabular}

*According to the Regulations on categories, testing and classification of waste ("Official Gazette RS", No. 56/10) for waste depositing on the landfill of hazardous waste, ${ }^{\star \star}$ Calculated per $\mathrm{kg}$ of sample, dry weight

By comparison the obtained results and allowable concentration of elements in the waste, according to the Regulations on categories, testing and classification of waste ("Official Gazette RS", No. 56/10), the contaminated soil sampled in the valley of the Bor River may be deposited onthe landfill for non-hazardous waste, but due to the acidic character of the resulting eluate, a condition is not satisfied which stipulates that the $\mathrm{pH}$ value of eluate must be higher than 6 as the waste may be deposited on the hazardous waste landfill. Due to this reason, the contaminated soil, as well as waste material, is possible to be safely deposited on a hazardous waste landfill.

\section{CONCLUSION}

Based on the given analyses, the present pollutants in the soil have a decisive influence on the environmental pollution in Bor and its surroundings.

The main sources of pollutants originate from the activities that occur in the copper production process in RTB Bor. Industrial and mining waste water flow into the Bor River making it one of the most polluted rivers in Europe. This indicates a fact that it is necessary to treat the waste water before discharge into the Bor River. Because the precipitation causes the flooding of rivers and coastal contamination leading to a concentration of heavy metals and metalloids in the soil. The pollutants from the air are an additional effect of soil.

\section{Acknowledgement}

The authors are grateful to the Ministry of Education and Science for the financial support. This paper is result of Project TR 37001: The Impact of Mine Waste from RTB Bor to the Pollution of Waterways with a Proposal of measures and Actions to Reduce the Harmful Effects on the Environment.

\section{REFERENCES}

[1] V.Marinković, Lj.Obradović, M.Bugarin, G. Stojanović (2014) The Impact of Polluted Wastewater on Water Quality of the Bor River and Surrounding Groundwater, Mining \& Metallurgy Engineering, 3, 33-40.

[2] Lj.Obradović, J.Stanković, M.Bugarin (2013) Disposal of Hazardous Mining Waste - the Current Serbian and EU Legislation, Mining and Metallurgy Engineering, 3, 113-118. 
[3] Lj.Obradović, M. Bugarin, V. Marinković (2012) The Effect of Mine Facilities of RTB Bor on Pollution of the Surrounding Water Flows, Mining \& Metallurgy Engineering, 4, 185-198.

[4] B.Han, B.Altansukh, K.Haga, Z.Stevanovic, J. Radojka, R. Markovic, Lj. Avramovic, Lj. Obradovic, Y.Takasaki, N. Masuda, D. Ishiyama, A. Shibayama (2014) Copper Upgrading and Recovery Process from Mine Tailing of Bor Region, Mater. Eng. Resour., 23, 225-229
[5] Z.Stevanovic (2007) Mining Master Plan Study: Copper Institute Service Activities for the Study on Master plan for Promotion of Mining Industry in Republic of Serbia. Client JICA Study Team Japan, p.380.

[6] Lj. Avramović, R.Jonović, M.Bugarin, R.Marković, J. Stevanović, M.Jonović (2014) Leaching of Flotation Tailings, 18th International Research /Expert Conference "Trends in the Development of Machinery and Associated Technology" TMT 2014, Budapest, Hungary, 10-12 Sept. 2014, p.481-484.

\section{IZVOD}

\section{KARAKTERIZACIJA ZEMLJIŠTA U PRIOBALJU BORSKE REKE}

Proizvodni proces dobijanja bakra u Rudarsko topioničarskom basenu (RTB) Bor direktno utiče na zagađenje životne sredine u Boru i okolini. Štetni elementi prisutni u vazduhu se talože na površini i usled dejstva atmosferskih padavina prodiru $u$ dublje slojeve zemljišta. Sa druge strane $u$ području dejstva RTB Bor prisutna su značajna zagađenja reka I zemljišta u priobalnom prostoru usled povećanja koncentracije prisutnih teških metala. Posebno je ugrožena Borska reka u kojoj su se godinama ulivale otpadne industrijske I rudničke vode. Borska reka je vremenom postala jedna od najzagađenijih reka u Evropi.

U radu su dati rezultati fizičko hemijske karakterizacije uzoraka zemljišta iz priobalja Borske reke. Ispitivani su sledeći parametri zemljišta: sadržaj vlage, $\mathrm{pH}$ vrednost, nasipna masa, specifična masa, granulometrijski sastav, hemijski sastav, toksične karakteristike -TCLP metoda $i$ test izluženja-metoda za karakterizaciju izluženja otpada.

Dobijeni rezultati ukazuju da je zemljište kontaminirano teškim metalima i da je utvrđeno značajno odstupanje od dozvoljenih koncentracija posebno kod sledećih elemenata $\mathrm{Cu}, \mathrm{As}$, i Pb. Zemljište u priobalju Borske reke pripada kategoriji opasnog otpada I neophodne su mere prevencije $u$ skladu sa definisanom zakonskom regulativom.

Ključne reči: zemljište, karakterizacija, Borska reka.

\section{Naučni rad}

Rad primljen: 15. 01. 2016.

Rad prihvaćen: 17. 02. 2016.

Rad je dostupan na sajtu: www.idk.org.rs/casopis 